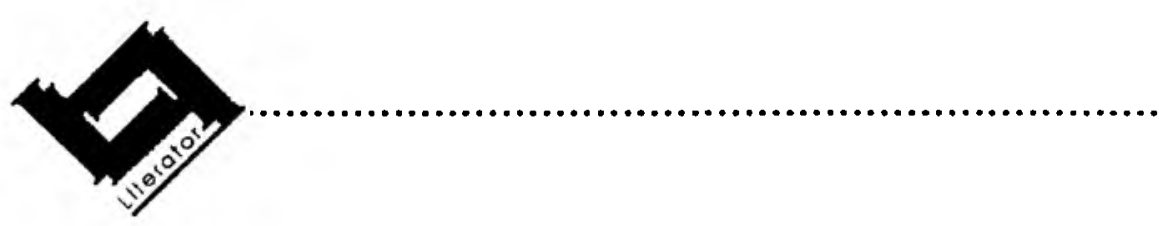

\title{
Tacitus se uitbeelding van Agrippina Minor
}

\author{
Marianne Dircksen \\ Skool vir Tale en Kunste: Latyn en Antieke Kultuur \\ Potchefstroomse Universiteit vir $\mathrm{CHO}$ \\ POTCHEFSTROOM \\ E-pos: klsmrd@puknet.puk.ac.za
}

\section{Abstract \\ Tacitus' portrayal of Agrippina Minor}

Ancient historiography has more in common with the historical novel than with modern historiography. The Annals of Tacitus should be seen as an artistic, narrative text which demands active participation by the reader in the process of interpretation. A narratological analysis of Tacitus' description of the life and death of Agrippina, mother of the emperor Nero, reveals a serious ethical reflection on the atrocities committed by the imperial family. Agrippina is characterised as an exceptionally strongwilled woman who had an immense influence on the Roman Empire while she was the wife of the emperor Claudius and mother of his successor, Nero. On the other hand, her typically female character traits are accentuated from which the reader has to infer that it was precisely the fact that she was a woman which made her authoritative position intolerable.

\section{Antieke geskiedskrywing}

Wanneer 'n twintigste-eeuse leser die werk van 'n antieke geskiedskrywer soos Tacitus (c. 55-117) lees, moet hy allereers nie dieselfde standaarde van sorg en feitelike korrektheid verwag as wat met moderne geskiedskrywing vereenselwig word nie. Daar is verskeie redes hiervoor:

- Romeinse geskiedskrywers soos Sallustius, Livius en Tacitus het 'n grondige opleiding aan die skool van die rhetor ontvang, wat gelei het tot 'n sterk retoriese inslag in hul werk. Die doel van die redenaar is om sy luisteraar op subtiele wyse tot sy standpunt oor te haal. Die retoriese stylmiddele en truuks verleen 'n dimensie aan hierdie outeurs se werk wat nie volledig uit die 
werklikheid kontroleerbaar is nie. Tacitus se gebruik van retoriese stylmiddele word deur Ryberg (1942:384) soos volg verduidelik: “... they are the resources employed by Tacitus the artist to produce an impression for which Tacitus the historian is not willing to take responsibility."(Vgl. ook McDonald [1975] vir 'n bespreking van hierdie onderwerp.)

- Romeinse geskiedskrywing was altyd nou verweef met die politiek (Dircksen, 1996:42 e.v.), maar in die Keisertyd kry die verband tussen politiek en geskiedskrywing 'n nuwe betekenis. In hierdie tye was openlike kritiek van die regerende magte gevaarlik, en was dit noodsaaklik om van suggestie gebruik te maak. Die oortuigingskrag hiervan was natuurlik ook veel groter as wat direkte aantygings sou wees. Ahl (1984:184) verwoord hierdie tendens by skrywers soos volg: "Many ancient poets, and all rhetorical theorists, lived when overt criticism of the ruling powers was dangerous. They sensed the need for obliqueness. But they also sensed the greater persuasiveness of oblique suggestion." (Vgl. ook Heubner, 1963:14-15.)

- Vir sowel die Grieke as die Romeine was geskiedskrywing altyd 'n artistieke produk. Die dramatiese van 'n spesifieke tydperk, die botsing tussen kontrasterende persoonlikhede, wat aan die kem van die drama gelê het, word uitgebeeld volgens die kanon van artistieke prosa (vgl. Laistner, 1947:8).

- Geskiedskrywing het in antieke tye altyd 'n etiese doelstelling gehad. Die gebeure waarop die outeur wou fokus, het ernstige morele nadenke uitgelok. Goed en kwaad is dikwels beklemtoon en gekontrasteer (Grant, 1970:278).

Dit is ook 'n ope vraag of 'n objektiewe oordeel selfs van moderne geskiedskrywers vereis behoort te word. Geskiedskrywers van alle periodes word onvermydelik in ' $n$ meerdere of mindere mate beïnvloed deur ' $n$ eie oorgeërfde wêreldbeskouing (Barret, 1996:xiv).

Uit wat hierbo gesê is, blyk duidelik dat die klem in 'n analise van Tacitus se Annales nie behoort te val op feitelike korrektheid of algehele objektiwiteit nie. Literêre kriteria sou met groter vrug aangewend kon word as die historiese maatstawwe wat geld vir die moderne geskiedskrywing. Tacitus as literêre kunstenaar skep 'n sekere indruk in sy lesers se gemoed en die implikasie is dat Tacitus, die geskiedskrywer, dit nie as sekerhede kon weergee nie, omdat sy idees onbevestig is, of selfs weerspreek word deur opgetekende feite. Ook in die weergawe van gerugte word valse hoorsê nie duidelik onderskei van feite nie. Die rapportering van gerugte moet dus ook as 'n literêre middel geïnterpreteer word eerder as 'n historiese een. Daitz (1960:52) som die literêre eienskappe van Tacitus se werk soos volg op: "The total effect ... is undeniably that of a literary tour de force which modern historians would probaly hasten to avoid and which novelists would most certainly be anxious to achieve". 
Dit is dus nie die doel van hierdie artikel om, sover dit moontlik is, "die waarheid" rondom Agrippina se doen en late hier op aarde vas te stel nie. ${ }^{1}$ In die onderstaande narratologiese analise van Tacitus se vertelling van die verhaal van die berugte Agrippina, moeder van Nero, word die Annales beskou as 'n artistieke, verhalende teks, wat nie noodwendig altyd die toets van feitelike korrektheid slaag nie. Die artistieke teks beskik verder oor 'n dimensie wat van die leser die konstruksie van die "ongeskrewe" teks vereis (Eco, 1979:10). Daarom sal daar nie volstaan word met 'n blote herkenning en beskrywing van die narratiewe aspekte nie, maar sal gepoog word om die data wat uit die beskrywing verkry is, te interpreteer.

\section{Die storie}

Die storie van Agrippina se lewe, soos dit in die Annales (XII, XIII en XIV (passim)) van Tacitus ontvou, verloop soos volg: Agrippina is gebore in Oppidum Ubiorum as die dogter van die beroemde veldheer Germanicus en Agrippina Maior, 'n kleindogter van Augustus. Agrippina se eerste huwelik was met Gnaius Domitius Ahenobarbus, en Domitius (die latere keiser Nero) was hul seun. Daar word aan Agrippina voorspel dat haar seun haar sou vermoor en sou heers (Ann. XIV,9). Tydens die keiserskap van haar broer Gaius word sy van sameswering verdink en verban. Sy is deur keiser Claudius, haar pa se broer, na Rome teruggeroep en na die dood van sy vrou Messalina is Agrippina een van die kandidate vir 'n huwelik met die keiser. Agrippina verlei Claudius, 'n verhouding ontstaan tussen hulle en toe Agrippina eers seker is van haar huwelik met Claudius, begin sy om die huwelik tussen haar seun, Domitius (Nero), en Claudius se dogter, Octavia, te beplan. ${ }^{2}$ Vitellius, die censor, oortuig die senaat van die noodsaaklikheid van Claudius en Agrippina se huwelik en die senaat verklaar dit geldig ten spyte van die familieverwantskap tussen hulle. Agrippina laat onmiddellik haar invloed in die ryk geld en Nero en Octavia raak verloof. Pallas, 'n vrygelate slaaf wat Agripinna se handlanger en minnaar was, bewerkstellig dit dat Nero deur Claudius aangeneem word. Agrippina vergiftig Claudius. Sy vertraag eers die aankondiging van sy dood om die lojaliteit van die troepe te verseker. Na Claudius se dood beklee Agrippina as moeder van die keiser steeds 'n ongeëwenaarde magsposisie, maar daar is tekens van vervreemding tussen moeder en seun. Die onmin tussen hulle word so erg dat Agrippina dreig om Britannicus, Claudius se seun by Messalina, te ondersteun.

1 So 'n studie is deur Barret (1996) gedoen. Hy mak gebruik van al die literêre en ander antieke bronne tot sy beskikking en probeer om so ver as wat hierdie getuienis dit toelaat, 'n getroue weergawe van Agrippina se lewe te gee.

2 Claudius het twee kinders by sy vorige vrou, Messalina, gehad, naamlik Britannicus en Octavia wat toe onderskeidelik agt en nege jaar oud was. 
Nero elimineer Britannicus. Agrippina maak geld bymekaar en versamel mense om haar om 'n ondersteuningsbasis vir die stryd teen Nero te vorm. Nero se nuwe minnares, Poppaea, spoor hom aan om sy moeder te vermoor. Hy laat 'n boot op só 'n manier bou dat dit op see uit mekaar sal breek sodat Agrippina kon verdrink. Die plan misluk. Hy stuur agente om die moord op Agrippina te voltrek. Dankseggings word deur die hele Italië gehou vir Nero se redding uit die hand van sy moeder, maar Nero word deur haar spook geteister. Nero lê 'n klag weens sameswering teen sy ma. Agrippina se ou vyande keer terug uit ballingskap en haar vriende en ondersteuners word gestraf.

\section{Verteltegnieke}

Die verhaal van Agrippina word nie in die Annales as 'n ononderbroke reeks gebeure vertel nie. 'n Belangrike kenmerk van Tacitus se geskiedskrywing (en van alle "annale") is juis dat die stof in jaar-tot-jaar-verslae georden word. Aan die begin van elke jaar word die name van die nuutverkose konsuls vermeld en word al die gebeure van daardie jaar in Rome en die provinsies weergegee. Tussen die verhaal van ander gebeure van elk van die jare van 49 tot 59, word Agrippina se storie dus deur die loop van Boeke XII, XIII en XIV ingevleg. Deur hierdie tegniek, wat deur die genretradisie afgedwing word, word die leser telkens herinner aan die sterk, deurlopende rol wat Agrippina in die ryk gespeel het. Haar verhaal word 'n draad wat deur die hele vertelling loop en die los insidente saamsnoer.

In die vertelling van Agrippina se verhaal gebruik Tacitus verskeie verteltegnieke om die verhaal op die boeiendste en interessantste manier aan sy leser oor te dra. 'n Ondersoek na die kerngebeurtenisse en uitbreidings ${ }^{3}$ in die verhaal lewer interessante gegewens op. Dit is duidelik dat Agrippina se eie optrede in 'n groot mate die verloop van haar lewe bepaal. Sy bewimpel hoofsaaklik self haar huwelik met Claudius en sy speel die sleutelrol in die huwelik van haar seun, Nero, met die keiser se dogter, Octavia, en in sy aanneming deur Claudius. So verseker sy dat Nero keiser word en dat sy as moeder van die jong keiser 'n magsposisie in die Ryk beklee. Hierdie gebeure word deur Agrippina self veroorsaak en sy speel die hoofrol in die geskiedenis van hierdie tyd. Die motivering vir Agrippina se dade kan telkens teruggevoer word na haar allesoorheersende drang na mag. Dit was die rede vir haar huwelik met Claudius

3 'n Gebeurtenis kan gedefinieer word as die oorgang van cen toestand na 'n ander wat veroorsaak of ondergaan word deur een of meer karakters (Bal, 1978:20). 'n Gebeurtenis laat die storie langs sy horisontale as voortbeweeg. Uitbreidings daarenteen, is minder belangrike beskrywings of insidente. Dit kan bestaan uit inligting in 'n teks wat dui op 'n toestand, of wat 'n karakter, atmosfeer of filosofie definieer of wat 'n saak toelig. 
en waarom sy alles in haar vermoë gedoen het om te verseker dat haar seun sou heers. Agrippina se magsbelustheid word die belangrikste motief in die verhaal.

Sy is ten volle in beheer van sake totdat sy uiteindelik onvermydelik die slagoffer word van 'n situasie wat sy self geskep het. Terwyl sy die magsposisie beklee en deel uitmaak van die keiserlike regime, verloop alles soos wat sy beplan en is alle kerngebeure die gevolg van haar handelinge. Wanneer sy egter nie meer in guns by haar seun, die keiser, is nie, is haar handelinge futiel en die resultate onvoorsien. Sy word 'n blote pion in 'n magspel waaroor sy beheer verloor het. Dit is ironies dat die einste magsposisie van haar seun, waarvoor Agrippina haar so beywer het, ten slotte die oorsaak van haar eie ondergang is. Soos elke ander Romeinse burger was Agrippina ook uiteindelik onderworpe aan die onvoorspelbaarheid en wispelturigheid van die regeerder. Die Romeinse Ryk was nog lank nie gereed om 'n vrou as regeerder te aanvaar nie.

Die duur van gebeure in die verhaal varieer gedurig. Die pas van die vertelling neem byvoorbeeld merkbaar af by belangrike en dramatiese momente in Agrippina se lewe. Voorbeelde hiervan is haar huwelik met Claudius (XII,1-7), die moord op hom (XII,66-68), die dood van Britannicus (XIII,16), en die verhaal van Agrippina se einde (XIV,1-9). Agrippina se ongeëwenaarde magsposisie en die latere stelselmatige afname van haar mag word weer geskets deur die opeenvolging van verskeie insidente wat net kortliks vermeld word. In die res van hierdie artikel word nagegaan hoe Tacitus die leser met die behandeling van elk van hierdie grepe uit Agrippina se lewe bewus maak van sekere onderliggende motiewe en terselfdertyd gestalte gee aan 'n komplekse beeld van hierdie merkwaardige vrou. Daar sal in die besonder aandag geskenk word aan die volgende narratologiese aspekte: seleksie, ritme, ruimte, karakterisering en die omkering van volgorde.

\section{Die huwelik met Claudius}

Claudius se besluit om met Agrippina te trou word volledig gemotiveer. Die voordele wat 'n huwelik met elk van die kandidate vir Claudius ingehou het, word om die beurt deur hul drie vernaamste ondersteuners aan die keiser voorgehou (XII,2). Soos wat die reels van die retoriek voorskryf, word die deurslaggewende argument vir laaste gebêre, en daarom kom Pallas, wat vir Agrippina aanbeveel, laaste aan die beurt. Hy wys op die feit dat Agrippina die kleinseun van Germanicus saam met haar sou bring. Die keiser moes liewer hierdie roemryke afstammeling in wie die Juliese en Claudiese stamme verenig is ${ }^{4}$ ) aan homself verbind. So kon hy verseker dat 'n vrou van bewese

4 Agrippina se moeder (ook Agrippina) was die kleindogter van keiser Augustus (Juliese stam) en haar vader, Germanicus, was die broerskind van keiser Tiberius (Claudiese stam) 
vrugbaarheid nie die roem van die Caesars na 'n ander familie oordra nie. Agrippina se adellike afstamming wat so pertinent op die voorgrond geplaas word met haar toetrede tot die toneel, word 'n belangrike tema waarop later telkens teruggekom word. Die Romeinse leser sou die gewigtigheid van hoë geboorte in die destydse samelewing besef, en daarmee saam die deurslaggewende invloed wat die dogter en kleinseun van die beroemde generaal, Germanicus, op die lojaliteit van die leër sou hê. Die feit dat hierdie argument van Pallas die sterkste by Claudius geweeg het, is ' $n$ aanduiding van die keiser se (tipiese) allesoorheersende vrees vir ander aanspraakmakers op die troon. Dit was Claudius se agtervolgingswaan wat hom genoop het om so 'n sterk aanspraakmaker op die troon aan homself te verbind eerder as om hom as opponent te hê.

Agrippina het haar saak verder bevorder deur Claudius te verlei (XII,2). Sy het Claudius gereeld besoek, en alhoewel sy nog nie sy vrou was nie, het sy reeds die magte van 'n vrou uitgeoefen. Sodra sy seker was van haar huwelik, het sy begin planne beraam vir 'n huwelik tussen haar seun, Domitius, en die keiser se dogter, Octavia. Dit kon nie sonder 'n misdaad bewerkstellig word nie, aangesien Octavia reeds verloof was aan Lucius Silanus ${ }^{5}$. Vitellius, die censor, het hom met Agrippina se planne vereenselwig om sodoende haar guns te wen $(X I I, 4)$. Hy het valse aanklagte teen Silanus ingebring wat geïmpliseer het dat hy bloedskande met sy suster, Calvinia, gepleeg het. So is Silanus se ondergang bewerkstellig. Alhoewel hul huwelik deur gerugte en deur hul onwettige liefde bevestig is (XII,5), het Agrippina en Claudius steeds nie die moed gehad om die plegtigheid te vier nie, aangesien daar geen presedent bestaan het vir 'n huwelik tussen 'n oom en sy niggie nie. Die verhouding was bloedskandelik. Vitellius het weereens tot hul redding gekom. Hy regverdig die huwelik van Claudius en Agrippina voor die volk en die senaat. In sy argument word 'n tweede verwysing na Agrippina se hoe geboorte aangetref (XII,6). Die feit dat die keiser met sy broer se dogter trou, word deur Vitellius weggeredeneer. Die lede het uit die senaatshuis gestorm terwyl sommige gesê het dat hulle die keiser tot die huwelik sou dwing as hy nog aarsel (XII,6). 'n Deurmekaar menigte het gou bymekaargekom en hulle het uitgeroep dat die huwelik die versoek van die volk was. Claudius het hulle in die forum ontmoet en hul gelukwensings ontvang. Daarna het hy die senaat binnegegaan en versoek dat ook huwelike tussen ooms en hul broers se dogters in die toekoms wettig sou wees.

Die episode illustreer duidelik hoe dit gebeur het dat die keiser bo die wet verhewe was en hoe almal as gevolg van hul slaafse onderdanigheid saamgespeel het om sy optrede, wat teen die wette van mense en gode was, aanvaarbaar te maak. Tacitus selekteer juis dié gebeure wat hierdie klugspel onderstreep.

$5 \quad$ Silanus was self 'n agterkleinseun van Augustus. 
Op die troudag het Silanus selfmoord gepleeg en is sy suster uit Italië verban (XII,8). Die ironie wat deur die hele vertelling aangevoel kan word, word nou pertinent uitgespel: Claudius het beveel dat versoenende seremonies vir die sondes van Silanus en sy suster by die woud van die godin Diana deur die priesters uitgevoer word en almal het gespot (inridentibus cunctis) omdat juis dié tyd uitgesoek is vir die straf en versoening vir bloedskande.

Wanneer Agrippina na haar huwelik met Claudius tot die toneel toetree, word die invloed wat sy op die ryk gehad het in 'n belangrike passasie beskryf:

Versa ex eo civitas et cuncta feminae oboediebant, non per lasciviam, ut Messalina, rebus Romanis inludenti. adductam et quasi virile servitium: palam severitas ac saepius superbia; nihil domi inpudicum, nisi dominationi expediret. Cupido auri immensa obtentum habebat, quasi subsidium regno pararetur (XII,7)

[dit was 'n veranderde staat en daar is gehoorsaamheid betoon aan 'n vrou, maar nie een soos Messalina wat argeloos die Romeinse staat as 'n speelding beskou het nie. Dit was 'n emstige slawerny, soos dié van 'n man: in die openbaar was daar strengheid en nogal dikwels hooghartigheid en tuis geen onkuisheid tensy dit tot heerskappy kon bydra nie. 'n Grenslose begeerte na goud het die verskoning gehad dat dit as 'n beskerming van die tirannie in gereedheid gebring word.]

Die woord virile val op. Agrippina se mag was sterk, byna manlik en het gepaard gegaan met 'n sekere hooghartigheid of trots en geldgierigheid.

\section{Die omvang van Agrippina se mag}

Die totale omvang van Agrippina se invloed word vir die leser duidelik uit die vermelding van die eerbewyse wat sy ontvang het en deur die feit dat sy sowel in staat was om in te tree om haar ondersteuners te help as om die ondergang van verskeie mense te bewerkstellig. So is Agrippina byvoorbeeld na haar seun se aanneming deur die keiser vereer met die titel Augusta (XII,26). Die Britse leier Caratacus het ook aan Agrippina eer bewys (XII,37) toe hy as gevangene na Rome gebring is. As Caratacus om begenadiging pleit, is sy opmerklik teenwoordig en haar ruimte word omskryf as "nie ver" (haud procul) van die Caesar af nie. Tydens die opvoering van 'n seegeveg op die Fucinusmeer $(X I I, 56)$ toe die meer met die Lirisrivier verbind is ${ }^{6}$ het Agrippina geklee in 'n goue Griekse mantel (chlamide aurata) weereens 'n ereposisie "nie ver" van (neque procul)

6 Die meer het tussen die Apennyne gelê en aangesien die watervlak baie gevarieer het, is besluit om 'n projek van Julius Caesar te voltooi en die meer in die Lirisrivier te laat dreineer deur 'n tonnel deur die heuwel wat tussenin gelê het, te grawe. 
die keiser ingeneem. Agrippina se fisiese ruimte word 'n metafoor vir haar posisie in die staat, want sy was ook wat die uitoefening van mag betref "nie ver" van die keiser af nie. Dis nie toevallig dat die kleur van die mantel vermeld word nie. Goud is sedert antieke tye die kleur en simbool van konings. Agrippina is toegelaat om die Capitolium in 'n klein koetsie (carpentum) binne te kom $(X I l, 42)$. In hierdie verband kom 'n volgende verwysing na haar uitsonderlike familieverbintenisse voor. Die eer om in die carpentum vervoer te word was vroeèr slegs vir priesters en heilige voorwerpe beskore. Die toekenning van hierdie voorreg het bygedra tot die verering van 'n vrou wat tot op daardie tydstip die enigste voorbeeld was van iemand wat die dogter van 'n imperator en die suster (van Caligula), die vrou en die moeder van 'n keiser was (... imperatore genitam, sororem eius, qui rerum potitus sit, et coniugem et matrem fuisse, unicum ad hunc diem exemplum est.) Sy bewerkstellig dat Seneca terugkeer as leermeester van Nero (XII,8); sy verkry die bevel oor die praetoriese wag vir Burrus (XII,42) en voorkom dat Vitellius vervolg word (XII,42). Sy is gemoeid met die ondergang van Lucius Silanus nog voordat sy met Claudius getroud is (XII,3-4) en daama sorg sy dat Junius Silanus (XIII,1), Lollia Paulina (XII,22), Statilius Taurus (XII,59) en Domitia Lepida (XII,64-65) vernietig word.

Die konvensies van die annalistiek werk ook hier ' $n$ bepaalde verteltegniek in die hand. Die lotgevalle van Agrippina se slagoffers word nie almal in een hoofstuk vermeld nie, maar elke geval word op sy kronologiese plek vermeld en herinner die leser telkens weer aan die donker wolk van moontlike vervolging en uitdelging wat gehang het oor diegene wat deur Agrippina as teenstanders beskou is. Die aankondiging van die dood van Junius Silanus heel aan die begin van Boek XIII werp onmiddellik 'n donker skadu oor die nuwe regime. In dieselfde sin word uitdruklik ontken dat Nero enigsins betrokke was by die moord (... ignaro Nerone - XIII,1). Die skuld word vierkantig op Agrippina se skouers geplaas (... per dolum Agrippinae paratur - XIII,1). Sy was bang dat Junius wraak sou neem op grond van sy broer (Octavia se verloofde) se dood en het hom om dié rede laat vergiftig (XIII, I). Statilius Taurus se rykdom was welbekend en Agrippina het sy tuine begeer (XII,59). Op grond van haar aanstigting is ' $n$ klag deur Tarquitius Priscus gelê wat geïmpliseer het dat Taurus tydens sy goewerneurskap van die provinsie Asia hom aan afpersing skuldig gemaak het. 'n Verdere aanklag is aanhangig gemaak op grond van sy geloof in toorkragte. Taurus het sy lewe geneem nog voor die uitspraak van die senaat gegee is. Agrippina was Lollia vyandiggesind omdat Lollia met haar meegeding het as een van die kandidate vir die huwelik met Claudius. Lollia is daarvan aangekla dat sy haar met die Galdeërs en towenaars opgehou het en die beeld van Apollo Clarius geraadpleeg het in verband met Claudius se huwelik. Calpumia, ook 'n vrou van hoë aansien, is uit die weg geruim omdat Claudius toevallig na haar skoonheid verwys het (XII,22). Agrippina se twis met Domitia Lepida was muliebris causis (om tipies vroulike redes). Daar was naamlik min te kies tussen die twee ten 
opsigte van afkoms, voorkoms, ouderdom en vermoë. Hulle was ook ewe onkuis, berug en gewelddadig sodat hulle in sowel ondeugde as deugde mededingers was. Hulle was ook in kompetisie oor wie die sterkste invloed oor Nero sou hê. Agrippina was die grimmige en dreigende moeder, wat vir haar seun 'n ryk wou gee maar wat nie kon verduur dat hy heers nie, terwyl Domitia die vrygewige tante was wat die dinge gesê het wat Nero graag wou hoor (XII,64). Die aanklag teen Domitia was dat sy toorkrag teen die keiser se vrou gebruik het, dat sy nie haar slawe in Calabria in toom kon hou nie en dat sy sodoende die vrede van Italië bedreig het. Sy is op hierdie aanklagte ter dood veroordeel.

Dit is insiggewend dat die feite van elke saak in besonderhede weergegee word. Die onregverdigheid van elke aanklag en die gemak waarmee skuldigbevindings deur die lede van die keiserlike regime verkry is, word pertinent onder die leser se aandag gebring.

'n Uitbreiding neem soms die vorm van 'n ingebedde verhaal aan en word dikwels aangewend om onderliggende temas te illustreer. Die verhaal van Narcissus beklemtoon die omvang van Agrippina se magsposisie as vrou van die keiser en wys ook op die lot van die onderdaan wat in opstand teen 'n lid van die keisershuis gekom het. Narcissus was uiters lojaal teenoor Claudius (XII,65). Hy was die een wat Claudius ingelig het oor sy vorige vrou, Messalina, se ontrouheid en sodoende haar ondergang bewerkstellig het. Sy antagonisme teenoor Agrippina blyk reeds wanneer Agrippina op die toneel verskyn as een van die kandidate vir 'n huwelik met Claudius en hy Claudius aanraai om eerder met Aelia Paetina ${ }^{7}$ as met Agrippina te trou (XII,1 en 2). Later was Narcissus in bevel van die projek waardeur die Fucinus-meer en die Lirisrivier deur middel van 'n tonnel met mekaar verbind is. Toe dit tydens die bekendstelling van die projek blyk dat daar wanbesteding van geld was, blameer Agrippina vir Narcissus. Hy bly ook nie stil nie maar maak 'n aanval op haar vroulike heerssug (inpotentiam muliebrem) en haar oormaat ambisie (nimias spes). Toe Agrippina die ondergang van haar teenstander Lepida bewerkstellig het (XII,64 en 65), het sy met sterk teenkanting van Narcissus te doen gekry (multum adversante Narcisso). Narcissus was diep bekommerd oor Agrippina se doen en late en oor die gevaar waarin hy verkeer het. Sy gesondheid het ingegee en hy het na Sinuessa gegaan om sy kragte te herwin. Agrippina het hierdie geleentheid gebruik om Claudius om die lewe te bring (XII,66). Na Nero se troonbestyging het Agrippina Narcissus gedwing om selfmoord te pleeg, al was dit teen die nuwe keiser se $\sin$. Narcissus se grootste sonde was dat sy lojaliteit op die verkeerde plek gelê het en dat hy die magsposisie van Agrippina onderskat het. Sy verhaal illustreer dat

Sy was reeds tevore met Claudius getroud, maar van hom geskei. 
openlike teenkanting of vyandskap met enige lid van die keiserlike regime tot gewisse uitdelging gelei het.

\section{Die dood van Claudius}

In haar beplanning van die moord op Claudius het Agrippina sorgvuldig navraag gedoen oor die geskikste soort gif (XII,66). As die gif se uitwerking te vinnig was, sou almal 'n misdaad vermoed het. As die gif weer te lank geneem om 'n effek te hê, kon Claudius besef het dat sy einde naby was. Hy kon ook van haar verraad bewus word en meer toegeneë tot sy eie seun word. Die gif moes Claudius dus deurmekaar maak, maar sy dood uitstel. 'n Vrou met die naam Locusta, wat bedrewe was op hierdie gebied, het die regte soort gif voorsien en die eunug, Halotus, wat altyd die kos moes proe, sou dit toedien. Daar word vertel dat die gif op 'n sampioen gesprinkel is. Weens Claudius se natuurlike traagheid of dalk omdat hy besope was, het hy nie dadelik die effek gevoel nie en boonop het 'n stoelgang tot sy redding gekom. Agrippina was hewig ontsteld en het op die dokter Xenophon, wat reeds vooraf oor alles ingelig is, se nommer gedruk. Hy het gemaak asof hy die keiser wou help om te braak en het 'n veer wat in vinnigwerkende gif gedoop was, in sy keel afgedruk en so sy dood veroorsaak.

Claudius se dood word dus in fyn besonderhede beskryf. Daar is 'n duidelike vertraging in die tempo van die verhaal. Die leser se aandag word gevestig op die ironiese situasie dat ' $n$ intrige binne die keiser se eie huis lei tot sy ondergang. Claudius se wellustigheid het uitgeloop op sy bloedskandelike huwelik en dit het ten slotte sy dood veroorsaak. Keisers was nie heersers op wie se rasionele optrede staatgemaak kon word nie. Hulle was swakkelinge wat hul menslike drange vooropgestel het.

Die geleentheid tot karakteruitbeelding word ook benut. In hierdie toneel word Agrippina se kragdadigheid en vasberadenheid gekontrasteer met Claudius se lamsakkigheid en sy benewelde toestand (socordiane an vinolentia XII,67). Tog blyk Agrippina se tipies vroulike geneigdheid tot paniek, wanneer dit lyk asof Claudius die aanslag op sy lewe gaan oorleef (... exterrita Agrippina - XII,68).

Die keiser se toestand het veroorsaak dat die senaat byeengeroep is en die konsuls en priesters het geloftes afgelê ter wille van die veiligheid van die keiser (XII,68). Terselfdertyd is die lewelose liggaam van die keiser met doeke en warm verbande toegemaak terwyl sake in orde gekry is om Nero se opvolging te verseker. Agrippina het vir Britannicus teen haar bors vasgedruk asof sy deur droefheid oorweldig is en troos gesoek het. Sy het hom die ewebeeld van sy pa genoem en hom met voorwendsels teruggehou sodat hy nie uit sy kamer kon uitgaan nie. Agrippina het ook vir Britannicus se susters, Antonia en Octavia, teruggehou en al die deure met wagte afgesluit. Elke nou en dan het sy 
bekendgemaak dat dit beter gaan met die keiser. Agrippina se maatreëls was daarop gemik om die soldate te bemoedig. Verder het sy dinge vertraag sodat die geleë oomblik waartoe die Galdeërs gemaan het, kon aanbreek. Agrippina se uitgeslapenheid, haar berekendheid en haar valsheid blyk uit die vertelling.

Op die 13de Oktober, teen die middaguur, het die paleis se hekke oopgeswaai, en Nero, vergesel van Burrus, het na die praetoriese wag uitgestap. Nadat die prefek hulle gewaarsku het, het die wag Nero met uitroepe ontvang en hom in 'n drastoel getel. Daar word gesê dat sommige mense omgekyk het en gevra het waar Britannicus dan was. Toe niemand iets anders voorstel nie, het hulle berus in wat vir hulle aangebied is. In die vermelding van hierdie besonderheid lê kommentaar op die militêre bestel opgesluit. Die soldate was ruggraatloos en het nie belang gestel daarin dat reg en geregtigheid geskied nie. Solank daar na hulle belange omgesien is, was hulle tevrede.

Goddelike eerbewyse is aan Claudius gewy, en tydens sy begrafnis het Agrippina die grootsheid van haar oumagrootjie, Livia, vrou van Augustus, nageboots (XII,69). Agrippina se gewetenloosheid word hier onderstreep. Tydens Claudius se begrafnis het sy die vermetelheid gehad om 'n prominente rol te speel.

Twee dinge val op wanneer Tacitus se verslag van die moord op Claudius nagegaan word. In die eerste plek word klem gelê op die sorg waarmee Agrippina die hele moord beplan het. Sy het selfs 'n noodplan gereed gehad. Hierdie detail moet oortuigingskrag aan die verhaal verleen, omdat dit moeilik sou wees om te glo dat die moord so oop en bloot onder die oë van al die teenwoordiges gepleeg kon word sonder om agterdog te wek. Dit is ook 'n aanduiding van Agrippina se geslepenheid. Tweedens word die lot van Britannicus telkens onder die leser se aandag gebring. Simpatie word gewek vir hierdie slagoffer van die verraderlike keisersvrou wat hom onder valse voorwendsels in die paleis gehou het. Dit word baie duidelik gestel dat Britannicus die regmatige aanspraakmaker op die troon was en Nero die onregmatige. Dit is ook die gedagte waarmee die vertelling afsluit: Claudius se testament is nie gelees nie om te voorkom dat die gemoedere van die volk opgesweep raak omdat die stiefseun ten koste van die eie seun bevoordeel is (XII,69).

\section{Die afname in Agrippina se mag}

Reeds kort na Claudius se dood word dit duidelik dat die verhouding tussen Agrippina en Nero besig was om te vertroebel (XIII,12). Die inkorting van haar magsposisie in die Ryk en die afname van haar invloed by Nero word in verskeie gebeurtenisse weerspieel. Die meeste hiervan word net kortliks vermeld. Die versnelde tempo van die vertelling versterk die idee van 'n snelle ineenstorting van haar mag. Aan sommige gebeure word meer aandag bestee en die vertraging in die tempo laat hierdie insidente uitstaan. 
Aan die begin van Nero se bewind veroorsaak Agrippina nog die dood van Junius Silanus (XIII,1) en Narcissus (XIII,1), maar dit word duidelik gestel dat laasgenoemde geval teen Nero se sin was (invito principe) en dat hy reeds moordgedagtes jeens Agrippina gekoester het (Ibatur in caedes - XIII,2). 'n Verdere aanduiding van die afname van haar invloed is die feit dat Seneca en Burrus, vir wie sy vroeër in die bres getree het, albei nou 'n stryd teen haar voer (Certamen utrique unum erat contra ferociam Agrippinae - XIII,2), en dat Nero ' $n$ renons in haar vertroueling Pallas gehad het (XIII,2). Sy word net nog in die openbaar (... propalam ...), vereer. Nero se wagwoord aan die wag by die paleis is "die beste van moeders" (XIII,2), en die senaat ken aan haar twee liktore toe asook die priesterskap vir die verering van die vergoddelikte Claudius, maar haar pogings om op die voorgrond te tree word telkens verydel. As sy kapsie daarteen maak dat 'n nuwe dekreet die verordening van Claudius tot niet maak (XIII,5), word die dekreet nogtans deurgevoer. Die senaat het wel in die Palatium byeengekom sodat sy by ' $n$ nuwe deur wat aangebring is, kon stelling inneem. Van agter 'n gordyn kon sy hoor wat aangaan al kon sy nie gesien word nie. Toe sy egter op Nero se verhogie wou klim om saam met hom 'n Armeense deputasie te woord te staan, het Seneca Nero gemaan om af te klim en sy moeder tegemoet te gaan en so 'n stokkie voor haar plan gesteek (XIII,5).

Nero se liefdesverhouding met die vrygelate slavin Acte, en sy ongewenste vriendskappe met Marcus Otho (die latere keiser) en Claudius Senecio word as die direkte oorsaak van die finale breuk tussen moeder en seun vermeld (Ceterum infracta paulatim potentia matris - XIII,12). Die episode rondom Acte word in groter detail beskryf en die tempo van die vertelling neem sodanig af dat dit die pas van ' $n$ toneel bereik. Tacitus vertel dat selfs Nero se ouer vriende geen gevaar daarin gesien het dat ' $n$ ou meisietjie (muliercula - XIII, I2) sonder enige skade aan enigeen, die begeertes van die keiser vervul nie. Ten spyte van haar hoë geboorte en beproefde eerbaarheid het hy 'n afkeer van sy vrou, Octavia, gehad en as sy wellus aan bande gelê is, was daar altyd die gevaar dat dit ten koste van vroue van aansien tot uiting kon kom. Maar Agrippina het uitgevaar teen "haar mededinger die vrygelatene" en "haar skoondogter die slavin" en nog ander dinge in dieselfde trant (XIII,13).

Die vorm van indirekte rede waarvan hier gebruikgemaak word, verdien spesiale vermelding. Dit bied 'n goeie voorbeeld van wat in die narratologie bekend staan 8 as "vrye indirekte diskoers". Vrye indirekte diskoers wek die indruk dat direkte en indirekte diskoers gekombineer word. In Latynse prosa beteken dit dat die oratio obliqua (indirekte rede) gebruik word, en dat persoonlike en besitlike

8 Vgl. Dircksen, (1996:140). Rimmon-Kenan (1983:110) gee 'n lys publikasies waarin hierdie vorm van diskoers aandag $\mathrm{kry}$. 
voomaamwoorde in die derde persoon sal wees, maar dat die taal gekleur is om by die karakter te pas eerder as by die verteller. Die funksie van hierdie stukkie vrye indirekte diskoers is veral om die spreker, Agrippina, te identifiseer. Haar hooghartige trots kom aan die lig terwyl haar bitsigheid in die bytende sarkasme weerspieël word.

Agrippina wou nie wag tot Nero berou kry of tot hy genoeg gehad het nie. Hoe meer sy verwyt het, hoe meer het sy die vuur aangeblaas. Nero was so verlief dat hy nie meer aan sy moeder onderdanig was nie, maar Seneca in sy vertroue geneem het. Seneca se vriend, Annaeus Serenus, het reeds voorgegee dat hý die verhouding met Acte gehad het en daarom was almal onder die indruk dat Nero se geskenke van Serenus af gekom het. Nou het Agrippina haar taktiek verander en Nero begin vlei en selfs die privaatheid van haar slaapkamer aangebied vir die bevrediging van sy drange. Sy erken dat sy te kras opgetree het en gaan tot die anderste uiterste oor wanneer sy hom haar fortuin aanbied. Die grootte van haar materiële vermoë word ook beskryf as "nie ver" van dié van 'n keiser nie: suarum opum, quae haud procul imperatoriis aberant, copias ... (XIII,13). Nero was nie blind vir die verandering nie en is ook deur sy vriende gewaarsku om op sy hoede te wees vir die lokvalle van 'n vrou wat nie alleen kwaai (atrox) was nie, maar ook vals ( XIII,13).

Waarom kry hierdie episode soveel aandag? Binne een hoofstuk word Agrippina uitgebeeld as onredelike tiran en as kruiperige onderdaan. Dit het tot Agrippina deurgedring dat Nero besig was om in 'n tipiese heerser te ontwikkel. Om sy guns te wen moes Agrippina haar soos 'n tipiese, nederige afhanklike gedra. Sy wend haar tot vleiery en die oordrewe onderdanige houding van 'n onderdaan.

Direk hierna word vertel hoe Nero, nadat hy gekyk het na die versierings wat eenmaal aan vroue en moeders van keisers geskitter het, 'n rok en juwele uitgesoek het en aan sy moeder as geskenk gestuur het (XIII,13). Daar was geen suinigheid in sy optrede nie, aangesien hy uit sy eie waardevolle items gestuur het wat deur ander begeer is. Agrippina het egter geprotesteer dat hy haar nie soseer met die geskenk wou verryk nie, maar haar eerder van die res ontneem het (XIII,13). Hy was volgens haar besig om dit uit te deel wat hy nie in geheel aan haar wou gee nie. Hierdie episode maak dit duidelik dat Agrippina, ten spyte van haar pasvermelde onderdanigheid, nog nie gereed was om haar posisie prys te gee en soos enige ander burger met dankbaarheid te aanvaar wat die keiser aan haar skenk nie. Nero se reaksie op sy moeder se hooghartigheid was om Pallas uit sy invloedryke posisie te verwyder. Dit is duidelik dat Nero die stryd teen sy moeder hervat het omdat sy dit nou duidelik gemaak het dat sy tog nie van plan was om permanent die rol van dankbare onderdaan te speel nie. Agrippina was woedend oor die ontslag van Pallas. In haar heftige reaksie wat weereens as vrye indirekte diskoers weergegee word, dreig sy dat sy Britannicus as die ware aanspraak- 
maker op die troon sal ondersteun en dat sy haar eie misdade waardeur sy vir Nero die troon verkry het, op die lappe sou laat kom. Daar is by haar min twyfel dat sy, as die dogter van Germanicus, meer invloed by die soldate sal hê as die kreupele Burrus en die banneling Seneca. Die kwessie van Agrippina se afstamming en die invloed wat daaruit voortspruit, word dus weereens te berde gebring.

\section{Die moord op Britannicus}

Alhoewel Agrippina se mag reeds voor die moord op Britannicus besig was om te taan, is sy dood (Ann. XIII,15-16) die keerpunt in die storie van Agrippina se lewe. Die episode word in besonderhede beskryf en verkry daarom besondere klem. 'n Hele hoofstuk (XIII,15) word aan die aanloop tot die moord en die eerste onsuksesvolle poging gewy. Agrippina se dreigemente, haar geneigdheid tot geweld en die simpatie wat Britannicus geniet het, word as Nero se vernaamste motivering vir die moord vermeld. Aangesien al Britannicus se kos eers geproe is, is die volgende plan beraam: Britannicus is eers 'n skadelose drankie wat baie warm was, aangebied. Die gif is toe saam met die koue water wat by die drankie gevoeg is, toegedien. Britannicus se stem sowel as sy asem het onmiddellik verdwyn. Nero het kalm gebly, maar vrees en paniek (pavor ea consternatio mentis) het Agrippina beetgepak en dit was duidelik dat sy in die duister was. Agrippina was nou nie meer die beplanner nie en dinge het nie langer volgens haar wil geskied nie. Haar rol verander van iemand wat voordeel getrek het uit die gehate keiserlike mag na dié van slagoffer. Sy het vroeër self Claudius se dood deur vergiftiging bewerkstellig, maar is nou die passiewe toeskouer van so 'n moord. Die oomblik van waarheid as Agrippina besef dat die presedent vir moedermoord geskep is (parricidii exemplum intellegebat), word 'n belangrike moment in die verhaal. Die fase van haar lewe waarin sy septer geswaai het, eindig hier en die verhaal van haar dood neem op hierdie stadium 'n aanvang. Die fatale fout wat Agrippina begaan het, was om te dreig dat sy 'n ander aanspraakmaker op die troon (Britannicus) sou ondersteun. Die grootste vrees van elke keiser was juis dat hy vervang sou word deur 'n persoon van goeie afstamming en iemand wat boonop die lojaliteit van die leêr geniet. Die moord op Britannicus illustreer die tipiese omstandighede rondom die uitwissing van 'n potensiële slagoffer - 'n ondeurdagte aanmerking lei tot ' $n$ waansinnige vrees by die keiser wat, sonder om veel tyd te verspeel, stappe neem om aan die "gevaar" te ontsnap. Baie onderdane het in voortdurende vrees geleef omdat hulle geweet het dat die heerser onverwyld ontslae sou raak van enige persoon wat hy as 'n bedreiging beskou het. Die agtervolgingswaan van die keisers het tot die uitdelging van vele onskuldiges gelei. 


\section{Die dood van Agrippina}

Aanvanklik probeer Agrippina om paraat te wees vir die stryd teen Nero. Sy soek ondersteuning by Octavia en maak geld bymekaar vir die stryd teen Nero, maar hy ontneem haar van haar wag en sy word verskuif na die huis van haar ouma Antonia. Agrippina word fisies verwyder uit die keiserlike ruimte en dit word simbolies van haar verwydering vanuit ' $n$ magsposisie. As Nero haar besoek, kom hy omring deur soldate en vertrek na 'n piksoentjie (XIII,18). Alhoewel sy haar met 'n weldeurdagte toespraak suksesvol verweer teen Junia Silana se aanklag van verraad (XIII,19-21) is dit opmerklik dat daar nou anklagte teen haar gemaak word terwyl sy vroeèr die een was wat gesorg het dat vervolging ingestel word. Uiteindelik is Agrippina so desperaat om haar invloed te behou dat sy soos ' $n$ tipiese kruiperige onderdaan enigiets probeer om die keiser se guns te wen. Sy daal tot die heel laagste vlak wanneer sy bloedskande met haar seun beplan $(\mathrm{XIV}, 2)$. Tacitus vertel dat Agrippina se brandende begeerte om te heers haar daartoe gedryf het om, uitgevat en gereed vir bloedskande, haarself by verskeie geleenthede aan Nero aan te bied. Sy het die middaguur uitgesoek wanneer Nero reeds aangeklam was. 9 Haar onwettige liefdesverhouding met Claudius (amore inlicito XII,5) het vir haar die posisie van keisersvrou bewerkstellig, maar hierdie keer lei haar onkuisheid tot vernedering wanneer die einste Acte, teen wie sy vroeèr so uitgevaar het, 'n stokkie voor die beplande misdaad steek en haar seun net al hoe meer afsydig teenoor haar staan (XIV,3). Haar dade lei nou tot die teenoorgestelde resultaat van wat sy beplan het en maak nie meer kerngebeurtenisse uit nie, maar word blote uitbreidings wat dien om die onderliggende motiewe te beklemtoon.

Na die beweerde planne vir bloedskande het Nero private ontmoetings met sy ma vermy. As sy na haar tuine of die landgoed by Tusculum of Antium vertrek het, het Nero haar voorneme om te rus aangeprys. Ten slotte het hy gedink dat sy, waar sy ook al gehou mag word, tog vir hom 'n ergenis (praegravis XIV,3) ${ }^{10}$ sou wees. Waar haar ruimte aanvanklik "nie ver"van dié van die keiser was nie, is sy

9 Wat die aanklag van bloedskande betref, gee Tacitus (XIV,2) eers Cluvius se weergawe met vermelding van die bron. Hy gee ook Fabius Rusticus se weergawe waarvolgens Nero die leiding geneem het en dieselfde oudslavin 'n stokkie daarvoor gesteek het. Die ander bronne gee volgens Tacitus, dieselfde weergawe as Cluvius, en die gerug (fama) steun hulle ook. Tacitus laat die vraag oop of Agrippina werklik die idee gekry het vir so 'n afgryslike daad en of dit maar net geloofwaardig gelyk het dat sy aan die nuwe soort wellus sou dink As 'n jong meisie het sy immers weens die vooruitsig van magsverkryging owerspel gepleeg met Marcus Lepidus (haar swaer), toegegee aan die wellus van Pallas en 'n skandelike huwelik met haar $\infty \mathrm{m}$ aangegaan.

10 Volgens Walker (1952:59) suggereer die byvoeglike naamwoord praegrovis onheil vir die persone van wie Tacitus dit gebruik. 
eers uit die keiserlike paleis verwyder en ten slotte is geen ruimte meer vir haar veilig nie. Nero het besluit om haar dood te maak. Soos Agrippina verskeie soorte gif oorweeg het voor die moord op Claudius, skenk Nero nou versigtig oorweging aan al die verskillende metodes (XIV,3) waarmee hy sy moeder om die lewe kon bring. Die beplanning word al hoe fyner en beter gedoen. Daar is by elke nuwe geslag keisers groter bedrewenheid met die pleeg van misdade. Anicetus se plan waarvolgens 'n skip só gebou word dat dit op see uitmekaar val en die keisermoeder laat verdrink, is die toppunt van vindingrykheid en Nero is baie ingenome met die konsep (placuit sollertia XIV,4).

Nero maak staat op sy moeder se tipies vroulike geneigdheid om in gunstige dinge te glo (feminarum credulitate ad gaudia) wanneer hy gerugte van 'n versoening tussen hom en sy moeder versprei. So lok hy sy moeder na die jaarlikse viering van die fees van Minerva by Baiae. Weereens is ironie sterk aan die werk: 'n godsdienstige fees word gebruik as voorwendsel vir die goddeloosste van misdade. Na die fees sien hy haar af as sy na haar villa aan die ander kant van die baai vertrek. Sy besonder liefdevolle optrede teenoor sy moeder by hierdie geleentheid word soos volg verklaar: sive explenda simulatione seu periturae matris supremus aspectus quamvis ferum animum retinebat (hetsy hy daardeur uitdrukking aan sy valsheid gegee het, hetsy die laaste blik op sy moeder wat op die punt was om te sterf, selfs sy wrede siel tot nadenke gestem het - XIV,4). Die vredige toneeltjie op die boot met Agrippina wat teruglê en die slavin, Acerronia, wat oor haar voete leun en vrolik gesels oor die herstel van verhoudinge tussen moeder en seun, staan in skrille kontras met die oomblik van verraad as die teken gegee word en die plafon, swaar van die lood, val en die huisslaaf Creperius se lewe eis. Agrippina word gered deur die hoë kante van die lêbank en die skip breek nie in stukke nie. Totale verwarring ontstaan as dié wat bewus was van die komplot, probeer om die skip te laat kantel terwyl dié wat van niks weet nie, na die teenoorgestelde kant neig. Die moeder van die keiser behoort tydens 'n skeepsramp eerste na veiligheid gebring te word, maar as die naïewe Acerronia uitroep dat sy Agrippina is, word sy met allerlei skeepstoebehore toegetakel en vermoor.

Die uitgeslape Agrippina bly doodstil en ontsnap na haar villa. Sy oorweeg al die omstandighede en besluit dan dat die enigste verweer teen verraad is om dit ongemerk te laat verbygaan (solum insidiarum remedium esse sensit, si non intellegerentur - XIV,6). Sy stuur haar vrygelatene, Agerinus, om aan Nero te berig dat sy ongedeerd is en dat dit te danke is aan die goedgunstigheid van die gode en Nero se goeie geluk! Sy versoek hom om ondanks sy bekommernis haar tog nie te kom besoek nie, aangesien sy net rus nodig het. Die leser is baie bewus van die ironie van die situasie. Die enigste optrede van Agrippina, sê Tacitus, wat nie 'n voorgeëry was nie, maar eie aan haar gierige aard, was toe sy beveel het dat Acerronia se testament gesoek word en haar bates verseël word. Agrippina 
wou verseker dat iemand anders nie voor haar sy hande op Acerronia se besittings lê nie.

Nero was buite homself van vrees (pavore exanimis) toe hy hoor dat Agrippina aan die dood ontkom het - 'n aanduiding van die geweldige invloed wat sy op hom gehad het. Hy laat sy twee raadgewers, Seneca en Burrus, kom. Haar afstamming kom weer ter sprake as Burrus daarop wys dat die soldate te lojaal teenoor die huis van die Caesars en die nagedagtenis van Germanicus was om hul nageslag leed aan te doen (praetorianos toti Caesarum domui obstrictos memoresque Germanici nihil adversus progeniem eius atrox ausuros). Hier, in haar krisisoomblik, is selfs haar hoë geboorte egter geen waarborg teen die gewetenlose moorddadigheid van haar seun nie (XIV,7). Daar word staatgemaak op Anicetus, die vrygelatene, om die moord te pleeg. Dit is ironies en veelseggend dat 'n vrygelatene, vir wie familieverbintenisse van absoluut geen waarde of betekenis was nie en wie se voorouers nie eers Romeinse burgers was nie, sonder enige gewetensbesware kans gesien het om die dogter van Germanicus om die lewe te bring. Vrygelatenes wat buitengewone voorregte en magte geniet het, was 'n integrale deel van die keisershuis in hierdie tyd. Agrippina, met haar unieke afstamming, word juis die slagoffer van een van hierdie verderflike agente op wie se ondersteuning die keiser te eniger tyd kon staatmaak.

In Agrippina se kamer was 'n dowwe lig en daar was slegs een slavin by haar $(\mathrm{XIV}, 8)$. Die ruimte waarin Agrippina haar laaste ure deurbring, is een van absolute verlatenheid. Sy is afgesluit van haar ondersteuners daar buite. In haar laaste oomblikke word weer twee kante van haar persoonlikheid belig - enersyds is sy die bekommerde, weerlose en eensame vrou en andersyds die uitgeslape planmaker. Sy is tipies vrou as sy al meer en meer bekommerd raak omdat sy niks van haar seun of van Agerinus hoor nie en besef dat dinge nie goed lyk nie. Sy ervaar slegs eensaamheid en hoor onverwagse geluide en die aanduidings is dat 'n ernstige ramp wag. As die slavin uitgaan, laat Agrippina byna pateties hoor: "Verlaat jy my ook?" (Tu quoque me deseris - XIV,8) As sy egter vir Anicetus agter haar sien, vergesel van Herculeius die skeepskaptein en Obaritus, 'n hoofman in die vloot, is dit Agrippina, die toneelspeler, wat oorneem: As Anicetus gekom het om haar te besoek, kon hy maar berig dat sy herstel het. As hy 'n misdaad wou pleeg, glo sy niks oor haar seun nie. Anicetus het nie opdrag gehad om moedermoord te pleeg nie. In 'n laaste, desperate poging om haar eie lewe te red gee sy steeds voor dat sy geen vuilspel aan Nero se kant vermoed nie. Dit is eers as die hoofman sy swaard trek om haar te dood, en sy besef dat daar nou geen kans meer is om begenadig te word nie, dat die blufspel ophou en sy haar buik na hom toe uithou met die woorde, "Ventrem feri" ("Tref die buik!" $\mathrm{XIV}, 8)$. Uiteindelik is sy van alle skyn ontbloot en val die klem op haar rol as 
moeder. Haar eie boosheid vervaag en die fokus verskuif na die monster wat sy gebaar het. ${ }^{11}$

Die eenvoud van haar begrafnis en haar graf $(X I V, 9)$ staan in skerp kontras met die feit dat sy gedurende haar lewe in weelde geleef het en byna 'n diktator was. Dit is seker nie toevallig dat die ruimte waarin haar beskeie grafsteen staan, naby die diktator Caesar se villa was nie (propter et villam Caesaris dictatoris XIV,9).

In omgekeerde volgorde word die verhaal van die voorspelling van die astroloë na Nero se geboorte eers hier vertel. Toe Agrippina by hulle navraag gedoen het oor Nero se toekoms is daar aan haar gesê dat Nero sou heers en sy moeder sou vermoor. Hierop het sy geantwoord: "Occidat dum imperet" ("Laat hy vermoor, solank as wat hy maar heers" - XIV,9). Dit is belangrik dat die leser juis in hierdie stadium, terwyl die grusaamheid van die moord die simpatie vir Agrippina laat toeneem, herinner word aan die magsbelustheid wat haar lewensloop bepaal het.

Nero se geweldige wroeging na haar dood is weereens ' $n$ bewys van die sterk invloed van haar persoonlikheid (XIV,10). Soos wat hy gedurende haar lewe haar van hom wou verwyder, kan hy nou selfs nie langer in die ruimte bly waarin sy gesterf het nie en vlug hy na Napels. In sy brief aan die senaat vertel hy dat Agerinus 'n wapen by hom gehad het en van plan was om die keiser te vermoor. Agrippina het as gevolg van haar skuldige gewete die hoogste tol betaal. In die lys van aanklagte teen haar word haar strewe na mag weereens as dedecus ("'n skande" - XIV,11) beskryf. Niemand is geflous deur die verhaal van 'n beplande sluipmoord nie, maar met kenmerkende kruiperige onderdanigheid het die onderdane op verskillende maniere vir Nero oortuig van hul ondersteuning (XIV,12-13). Met sy terugkeer na die stad is hy net so entoesiasties ontvang as 'n generaal tydens sy triomftog, maar Nero het sý triomf gevier oor die volk se slaafsheid (publici serviti victor - XIV,13). Hy het nou vrye teuels gegee aan al sy ondeugde wat tot nou toe aan bande gelê is deur 'n soort ontsag vir sy moeder (seque in omnes libidines effudit, quas ... qualiscunque matris reverentia tardaverat - XIV,13). Agrippina het dus tot met haar dood 'n inhiberende uitwerking op Nero gehad.

11 In sy kenmerkende kriptiese styl laat Tacitus dit aan sy lesers oor om haar sterfwoorde aan te vul. Hy buit die dramatiese doeltreffendheid van die onderbeklemtoning uit. Dio Cassius (wat sy Romeinse geskiedenis in Grieks geskryf het), haal haar sterfwoorde soos volg aan: " $\pi \alpha i \epsilon ~ . .$.

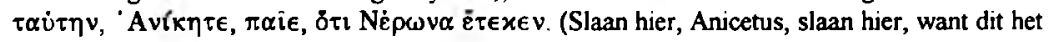
Nero voortgebring.) 


\section{Slotsom}

In die ondersoek na die verteltegnieke wat in die verhaal aangetref word, word sekere herhalende onderliggende motiewe duidelik. Hierdie motiewe word nie uitgespel nie, en is nie gebaseer op feite wat histories bo verdenking staan nie. Daar het byvoorbeeld geen onbevooroordeelde getuies bestaan wat Agrippina se optrede na Claudius se dood, of haar reaksies na Britannicus se dood aan die geskiedskrywer kon oordra nie. Tacitus het sy stof op so 'n manier gekies en aangebied dat 'n sekere indruk in die gemoed van die leser ontstaan wat belangriker as die histories bewysbare feite is.

Die gebeure in Agrippina se verhaal waarop Tacitus fokus, lok ernstige morele nadenke uit. Goed en sleg word gekontrasteer en daar is 'n duidelike etiese doelstelling te bespeur. Die agtergrond waarteen die verhaal van Agrippina afspeel, is 'n keiserlike regime wat sy mag ten alle koste wou behou. Hieruit spruit die agtervolgingswaan van die keiserlike familie en die ewige vrees waarin die onderdane geleef het, veral dié met adellike familieverbintenisse. Die pleeg van misdade om hul eie posisie te verstewig, is deur die regeerders tot 'n kuns verfyn en hierin was hul vrygelate slawe hul handlangers en vertrouelinge. Die regeerders kon met hul wandade voortgaan omdat die Romeinse onderdane ruggraatloos geword het en alles wat hul heersers gedoen het, met kruiperige slaafsheid goedgekeur het. Die onderdrukking is dus die gevolg van 'n onvermoe om op geregtigheid aan te dring.

Daar skemer ook 'n sekere wêreldbeskouing deur in die vertelling: gebeure word veroorsaak deur mense, nie deur die gode, toeval of die noodlot nie. Dit is die karakters van mense wat aan die geskiedenis vorm gee.

'n Ondersoek na die beeld van Agrippina soos wat dit uit Tacitus se verhaal van haar lewe duidelik word, lewer 'n interessante maar komplekse prentjie op. Dit blyk dat sy enersyds voorgestel word as 'n buitengewoon sterk vrou, van uitsonderlik hoe geboorte wat haar invloed op 'n byna manlike manier in die ryk laat geld het. Uit haar dade is dit duidelik dat sy kwaai, gewelddadig, hooghartig, geslepe en vals was. In die teks kom ook direkte beskrywings voor wat hierdie bevinding oor haar persoonlikheid staaf. Agrippina word met die volgende woorde beskryf: violentia (gewelddadig), trux (grimmig), minax (dreigend) (XII,64), atrox (wreed), falsa (vals) (XIII,13) en superbia (hoogmoed) (XII,7 XIII,14). Haar seksuele verleiding het slegs die verkryging van mag ten doel gehad en haar gierigheid kan toegeskryf word aan die feit dat sy hierdie mag ten alle koste wou beskerm. In teenstelling hiermee word daar ook dikwels melding gemaak van Agrippina se tipies vroulike eienskappe wat gewoonlik gekoppel word aan emosionele onstandvastigheid (vgl. Rutland, 1978:15-16). Die byvoeglike naamwoord muliebris (vroulike) word herhaaldelik van Agrippina gebruik (XIII,14, XII,57, XII,64, XIV,2 ). Toe Nero verlief geraak het op Acte 
het Agrippina "soos 'n vrou" getier (muliebriter fremere - XIII,13). Eienskappe soos liggelowigheid $(\mathrm{XIV}, 4)$ en jaloesie $(\mathrm{XII}, 64)$ wat as kenmerkend van vroue beskou word, word aan haar toegeskryf.12 Hoe is die beeld van manlike rigiditeit en vroulike onstandvastigheid te versoen? Agrippina se verbintenis met die huis van die Julii het aan haar 'n amper mistieke status gegee wat as kragtige basis gedien het vir die aansprake wat sy namens haar seun gemaak het. ${ }^{13}$ Daar was egter geen moontlikheid dat Agrippina as gevolg van haar afstamming 'n heerser in eie reg sou word nie (Barret, 1996:16). Die Romeinse ryk was nog lank nie gereed om vroulike heerskappy te verduur nie. Inteendeel, die ongehoord invloedryke posisie wat Agrippina beklee het, word herhaaldelik as skandelik beskryf en almal wou sien dat haar mag ondermyn word (cupientibus cunctis infringi potentiam matris - XIV,1). Sy moes van agter 'n gordyn na senaatsvergaderings luister (XIII,5) en toe sy nadergestaan het om die voorsitterstoel met Nero te deel toe hy die Armeense deputasie te woord gestaan het, het 'n skokgolf deur die omstanders getrek (ceteris pavore defixis - XIII,5). Seneca het Nero gemaan om sy moeder tegemoet te gaan en so is 'n skande afgeweer onder die voorwendsel van eerbied teenoor 'n ouer (Ita specie pietatis obviam itum dedecori - XIII,5). In die klagstaat wat Nero na haar dood opstel, word die woord dedecus weer gebruik in verband met haar (beweerde) pogings om mag te verkry $(\mathrm{XIV}, 11)$. Dit was skandelik om geen ander rede nie as dat Agrippina 'n vrou was.

Vroue was in die oë van Tacitus (en waarskynlik die hele gemeenskap) emosioneel, irrasioneel, onstandvastig en nie geskik om as heersers op te tree nie. Om hierdie rede word daar telkens klem gelê op die tipies vroulike aspekte van Agrippina se karakter. Agrippina het wel oor die eienskappe van 'n eerste-eeuse regeerder beskik, sy was beslis honger genoeg na mag en sy het sekerlik die regte afstamming gehad, maar sy was in die finale instansie 'n vrou, vir wie 'n magsposisie ontoelaatbaar was. Haar magsposisie het geen geldige basis gehad nie. Die kernprobleem rondom Agrippina se uitoefening van gesag word saamgevat in die volgende sententia: Nihil rerum mortalium tam instabile ac fluxum est quam potentiae non sua vi nixae. (Niks hier op aarde is so onstabiel

12 Daar word geen klem gelê op Agrippina se uiterlike skoonheid nie. Daar is slegs die terloopse opmerking dat daar min te kies was tussen haar en haar aartsvyand, Domitia Lepida, wat skoonheid (forma) betref het (XII,64). Standbeelde van Agrippina toon dat sy wel baje aanvallig was (vgl. Wood, 1995:457 e.v.). Agrippina se skoonheid was egter nie vir Tacitus belangrik nie; dit is die eienskappe van verstand en gees wat hom interesseer (Walker, 1952:190). Vgl ook Baldwin (1972:84) oor die feit dat Tacitus ook nie besonderhede oor die fisiese voorkoms van Agricola se moeder, vrou of dogter gee nie.

13 Oor die belangrikheid van afstamming deur die vroulike lyn, kyk Barret (1996: 16). 
en vlietend as roem wat geheg word aan mag wat nie op sy eie krag steun nie XIII,19.)

Dit is ten slotte juis Agrippina se sogenaamde vroulike eienskappe, haar onbeheerste getier (wat vir Nero te veel word) en haar liggelowigheid (as sy haar deur die gerugte van 'n versoening na Baiae laat lok), wat direk tot haar ondergang lei. Die boodskap van die teks aan die leser is duidelik: vroue wat in die magspel betrokke raak, speel met vuur

\section{Bibliografie}

Ahl, F. 1984. The art of safe criticism in Greece and Rome. American Journal of Philology, 105:174-208.

Bal, M. 1978. De theorie van vertellen en verhalen. Tweede uitgave. Muiderberg : Couthino Baldwin, B. 1972. Women in Tacitus. Prudentia, 4:83-101.

Barret, A.A. 1996. Agrippina. Sex power, and politics in the early empire. New Haven : Yale University Press.

Daitz, S.G. 1960. Tacitus' technique of character portrayal. American Journal of Philology, 81:30-52.

Dircksen, M.R. 1996. 'n Narratologiese analise van Tacitus, Historiae I, 1-49. Johannesburg : RAU.

Eco, Umberto. 1979. The role of the reader: Explorations in the semiotics of texts. Bloomington : Indiana University Press.

Grant, M. 1970. The ancient historians. London : Garden City

Heubner, H. 1963. P. Cornelius Tacitus. Die Historien. Heidelberg: Carl Winter. Universitatsverlag.

Laistner, M.L.W 1947. The greater Roman historians. Los Angeles : University of California Press

McDonald, A.H. 1975. Theme and style in Roman historiography. Journal of Roman Studies, 65:1-10.

Rimmon-Kenan, S. 1983. Narrative fiction: contemporary poetics. London : Methuen

Rutland, L.W. 1978. Women as makers of kings in Tacitus' Annals. Classical World, 72:1529.

Ryberg, I S 1942. Tacitus' art of innuendo Transactions and Proceedings of the American Philological Association, 73:383-404.

Walker, B. 1952. The annals of Tacitus. A study in the writing of history. Manchester Manchester University Press.

Wood, S. 1995. Diva Drusilla Panthea and the sisters of Caligula American Journal of Archaeology, 99:457-82. 
